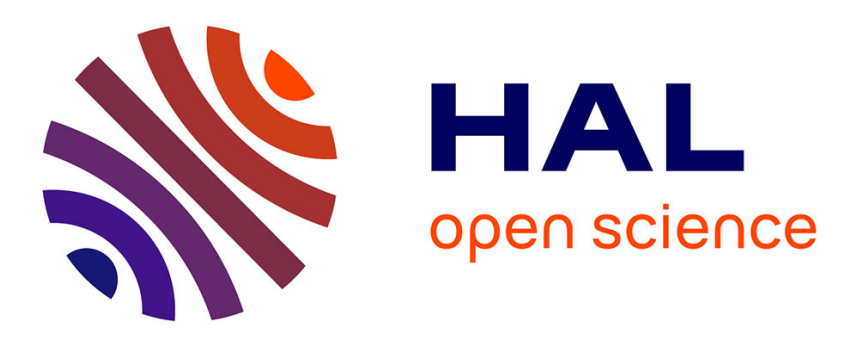

\title{
New wavelength measurements and laser lines in optically pumped methanol and methanol analogues
}

S. Huant, M. A. Hopkins, K. Karraï, G. Dampne, R.J. Nicholas, L.C. Brunel

\section{To cite this version:}

S. Huant, M. A. Hopkins, K. Karraï, G. Dampne, R.J. Nicholas, et al.. New wavelength measurements and laser lines in optically pumped methanol and methanol analogues. Revue de Physique Appliquée, 1987, 22 (3), pp.205-206. 10.1051/rphysap:01987002203020500 . jpa-00245532

\section{HAL Id: jpa-00245532 https://hal.science/jpa-00245532}

Submitted on 1 Jan 1987

HAL is a multi-disciplinary open access archive for the deposit and dissemination of scientific research documents, whether they are published or not. The documents may come from teaching and research institutions in France or abroad, or from public or private research centers.
L'archive ouverte pluridisciplinaire HAL, est destinée au dépôt et à la diffusion de documents scientifiques de niveau recherche, publiés ou non, émanant des établissements d'enseignement et de recherche français ou étrangers, des laboratoires publics ou privés. 


\title{
New wavelength measurements and laser lines in optically pumped methanol and methanol analogues
}

\author{
S. Huant, M. A. Hopkins $\left(^{+}\right)$, K. Karraï, G. Dampne, R. J. Nicholas $\left(^{+}\right)$and L. C. Brunel \\ Service National des Champs Intenses, Centre National de la Recherche Scientifique, BP 166 X, \\ 38042 Grenoble Cedex, France $\left(^{*}\right)$ \\ $\left({ }^{+}\right)$Clarendon Laboratory, Parks Road, Oxford OX1 3PU, United Kingdom
}

(Reçu le 6 août 1986, accepté le 25 novembre 1986)

\begin{abstract}
Résumé. - Nous présentons des mesures précises des longueurs d'onde de 8 raies fréquemment utilisées en spectroscopie laser dans l'infrarouge lointain, leurs longueurs d'onde citées dans la littérature étant erronées. Nous présentons également les mesures de 8 nouvelles raies que nous avons observées.
\end{abstract}

Abstract. - We present accurate measurements of 8 frequently used CW far infrared laser lines which we found substantially in error in the litterature. We also present measurements of 8 newly observed lines.

The optically pumped Far Infrared (FIR) molecular laser introduced by Chang et al. [1] provides a vast number of laser lines in the wavelength region from $\lambda=30 \mu \mathrm{m}$ to $\lambda=3 \mathrm{~mm}$. More than a thousand lines have been collected by Knight [2]. Cyclotron resonance studies in III-V semiconductor compounds in high magnetic fields have established the need for accurately known wavelengths in the short wavelength region $\lambda=30 \mu \mathrm{m}$ up to $\lambda=$ $200 \mu \mathrm{m}[3,4]$. In a recent study of resonant polaron effect in GaInAs based heterostructures we found out that some of the published FIR lines are substantially in error $[5,6]$.

In this communication we present accurate wavelength measurements of these lines together with the wavelength measurements of some new laser lines we have observed. We used a PL 4 Edinburgh $\mathrm{CW} \mathrm{CO}_{2}$ laser. The pump radiation was chopped at typically $30 \mathrm{~Hz}$ and then focused into the waveguide cavity made of a $1.5 \mathrm{~m}$ long, $17 \mathrm{~mm}$ inner diameter Pyrex tube place between two mirrors. The FIR output stability was greatly improved using the passive isolator for optically pumped far infrared lasers described by Mansfield et al. [7]. With such a device, the pump radiation is circularly polarized, no attempt was made to check the polarization of the emitted radiation. Depending upon the region of

$(*)$ The Service National des Champs Intenses is "Laboratoire associé à l'Université Scientifique, Technologique et Médicale de Grenoble ». interest we used two waveguide cavities. In the short wavelength region $30-70 \mu \mathrm{m}$, in order to obtain a good stability of the optical FIR resonator the cavity was designed with one flat and one concave mirror [8]. The fixed mirror was a flat gold plated brass mirror with a $1.5 \mathrm{~mm}$ central hole, the movable mirror was an aluminized glass mirror with a $3 \mathrm{~m}$ radius of curvature. In this region we used the in/out coupling system described by Sigg et al. [9]. Above $100 \mu \mathrm{m}$ we obtained higher FIR output power using the same fixed mirror and for the FIR output a movable mirror made of a flat aluminized glass mirror with a $4 \mathrm{~mm}$ central hole. In the intermediate region we used either one of the two waveguide cavities.

We measured the laser lines wavelengths with a Michaelson interferometer built in our workshop. The accuracy of this interferometer was checked against the wavelength of a number of precisely known laser lines $\left(\Delta \lambda / \lambda=10^{-7}\right)$. The wavelength measurements are accurate to $0.1 \%$ except for one line (see table II).

The pressure of the lasing medium was measured with an absolute gauge independent of the nature of the gas. The FIR output power, measured with a Golay cell, is quoted using a relative scale : very weak (VW) corresponds to roughly $0.01 \mathrm{~mW}$, weak (W) corresponds to $0.1 \mathrm{~mW}$ ard medium (M) corresponds to $1 \mathrm{~mW}$. The frequently quoted $46.7 \mu \mathrm{m}$ line (9 R 8) which we measure at $47.70 \mu \mathrm{m}$ would appear as medium on our scale. 
Table I. - New measurements of known FIR laser lines $\left(\mathrm{MA}=\mathrm{CH}_{3} \mathrm{OH}\right.$, DMA. $\mathrm{CH}_{3} \mathrm{OD}$, MAD. $\left.\mathrm{CD}_{3} \mathrm{OH}\right)$.

\begin{tabular}{|l|c|l|l|}
\hline $\begin{array}{c}\text { Quoted } \\
(\mu \mathrm{m})\end{array}$ & $\begin{array}{c}\text { Measured } \\
(\mu \mathrm{m})\end{array}$ & Gas & Pump \\
\hline 37.6 & 37.25 & MAD & $10 \mathrm{R} 34$ \\
40.1 & 40.28 & MAD & $10 \mathrm{P} 22$ \\
$41.0\left(^{*}\right)$ & $\{41.35$ & DME & $10 \mathrm{R} 18$ \\
46.7 & 43.70 & DME & $10 \mathrm{R} 18$ \\
57.0 & 57.70 & DMA & 9R8 \\
81.9 & 81.20 & DMA & 9R8 \\
89.6 & 89.30 & DMA & 9P30 \\
\hline
\end{tabular}

$\left({ }^{*}\right)$ See text.

In table I, we present our measurements of known laser lines we found in error while table II displays wavelengths measurements of new laser lines. The line quoted at $41 \mu \mathrm{m}$ for DME using $10 \mathrm{R} 18$ as a $\mathrm{CO}_{2}$ pump appears to consist of two lines at 41.35 and $43.70 \mu \mathrm{m}$ identical with the lines found with MAD with the same $\mathrm{CO}_{2}$ pump. These lines are stronger and more stable with MAD and we believe these lines are due to MAD contained in DME. Recently Sigg et al. [9] published a set of 25 new CW FIR lines. We measured some of them. Our results were always within the experimental accuracy these authors quote.
Table II. - Experimental conditions for newly observed FIR laser lines (MA13 : methanol with $\mathrm{C} 13$ isotope).

\begin{tabular}{|c|c|c|c|c|}
\hline $\begin{array}{c}\text { FIR } \\
\text { wavelength } \\
(\mu \mathrm{m})\end{array}$ & $\begin{array}{c}\text { FIR } \\
\text { power }\end{array}$ & Gas & $\begin{array}{c}\text { Pressure } \\
(\mathrm{mbar})\end{array}$ & $\begin{array}{c}\mathrm{CO}_{2} \\
\text { pump }\end{array}$ \\
\hline 51.40 & W & MAD & 0.5 & $10 \mathrm{R} 38$ \\
\hline 54.65 & $\mathrm{M}$ & MAD & 0.2 & $10 \mathrm{R} 18$ \\
\hline 68.21 & VW & MAD & 0.5 & $10 \mathrm{R} 36$ \\
\hline 88.7 & $\mathrm{M}$ & DMA & 0.5 & 9R32 \\
\hline 110.4 & W & DMA & 0.5 & 9P30 \\
\hline 122.3 & W & MAD & 0.3 & $10 \mathrm{R} 38$ \\
\hline 122.5 & M & DME & 0.5 & $10 \mathrm{R} 28$ \\
\hline $143.6\left(^{*}\right)$ & W & MA13 & 0.3 & 9P22 \\
\hline
\end{tabular}

$\left(^{*}\right)$ This line has been measured with an accuracy of $0.2 \%$.

In conclusion we measured with an accuracy convenient for magnetooptical experiments some frequently used FIR laser lines. The short wavelength spectrum has been improved using high performance waveguide cavities.

\section{References}

[1] Chang, T. Y., Bridges, T. J., BurkhardT, E. G., Appl. Phys. Lett. 17 (1970) 249.

[2] KNIGHT, D. J. E., Ordered list of FIR laser lines, Nat. Phys. Lab. Report QU 45 (1982).

[3] Horst, M., Merkt, U., Zawadzki, W., MaAn, J. C., PlooG, K., Solid State Commun. 53 (1985) 403.

[4] Sigg, H., Bluyssen, H. J. A., Wyder, P., Solid State Commun. 48 (1983) 897.

[5] Nicholas, R. J., Brunel, L. C., Huant, S., Karraï, K., Portal, J. C., Brummel, M. A., Razeghi, M., Cheng, K. Y., ChO, A. Y., Phys. Rev. Lett. 55 (1985) 883.
[6] Brunel, L. C., Huant, S., Nicholas, R. J., HopKinS, M. A., Brummell, M. A., KarRaÏ, K., Portal, J. C., Razeghi, M., Cheng, K. Y., CHO, A. Y., Proceedings of Electronic Properties of Two-Dimensional Systems, Surf. Sci. 170 (1986) 542.

[7] Mansfield, D. K., Semet, A., Johnson, L. C., Appl. Phys. Lett. 37 (1980) 688.

[8] YARIv, A., Quantum Electronics (John Wiley and Sons, New York) 1968.

[9] Sigg, H., Bluyssen, H. J. A., Wyder, P., IEEE, J. Quantum Electron QE 20, vol. 6 (1984) 30. 